\title{
Longevity and survival of Leptocybe invasa (Hymenoptera: Eulophidae), an invasive gall inducer on Eucalyptus, with different diets and temperatures
}

Amanda Rodrigues De Souza ${ }^{1}$, Leonardo Rodrigues Barbosa ${ }^{2}$, José Raimundo de Souza Passos ${ }^{3}$, Bárbara Monteiro de Castro e Castro ${ }^{\text {Corresp.., }}{ }^{4}$, José Cola Zanuncio ${ }^{5}$, Carlos Frederico Wilcken ${ }^{1}$

1 Faculdade de Ciências Agronômicas, Departamento de Proteção Vegetal, UNESP (São Paulo State University), Botucatu, São Paulo, Brazil

2 Embrapa Florestas, Empresa Brasileira de Pesquisa Agropecuária, Colombo, Paraná, Brazil

3 Instituto de Biociências, Departamento de Bioestatística, UNESP (São Paulo State University), Botucatu, São Paulo, Brazil

4 Departamento de Fitotecnia, Universidade Federal de Viçosa, Viçosa, Minas Gerais, Brazil

5 Departamento de Entomologia/ BIOAGRO, Universidade Federal de Viçosa, Viçosa, Minas Gerais, Brazil

Corresponding Author: Bárbara Monteiro de Castro e Castro

Email address: barbara.monteiro@ufv.br

The blue gum chalcid, Leptocybe invasa Fisher \& LaSalle (Hymenoptera: Eulophidae), causes galls on Eucalyptus spp. leaf midribs, petioles and stems. Biological aspects need to be studied to assist in developing management strategies and to maintain this insect in the laboratory to rear the parasitoid Selitrichodes neseri Kelly \& La Salle (Hymenoptera: Eulophidae) that depends on having a supply of Eucalyptus seedlings infested by L. invasa. We evaluated the longevity and survival of $L$. invasa individual non reproductive females fed with six different diets (pure honey, 50\% honey solution, pure honey plus eucalyptus leaves, eucalyptus leaves, distilled water, or no food) and seven different temperatures $\left(10,14,18,22,26,30\right.$ and $\left.34^{\circ} \mathrm{C}\right)$. Leptocybe invasa fed with $50 \%$ honey solution and reared at 14 or $18^{\circ} \mathrm{C}$ showed the greatest longevity and survival. 
1

2

6 Amanda Rodrigues de Souza ${ }^{1}$, Leonardo Rodrigues Barbosa ${ }^{2}$, José Raimundo de Souza Passos ${ }^{3}$;

7 Bárbara Monteiro de Castro e Castro ${ }^{4 *}$, José Cola Zanuncio ${ }^{5}$, Carlos Frederico Wilcken ${ }^{1}$

8

9 'Faculdade de Ciências Agronômicas, Departamento de Proteção Vegetal, UNESP (São Paulo 10 State University), Botucatu, São Paulo, Brasil.

11 2Empresa Brasileira de Pesquisa Agropecuária, Embrapa Florestas, Colombo, Paraná, Brasil.

$12{ }^{3}$ Instituto de Biociências, Departamento de Bioestatística, UNESP (São Paulo State University), 13 Botucatu, São Paulo, Brasil.

$14{ }^{4}$ Departamento de Fitotecnia, Universidade Federal de Viçosa, Viçosa, Minas Gerais, Brasil.

15 5epartamento de Entomologia/BIOAGRO, Universidade Federal de Viçosa, Viçosa, Minas 16 Gerais, Brasil.

17

18

19

*Corresponding author: barbaramcastro@hotmail.com 


\section{Abstract}

22 The blue gum chalcid, Leptocybe invasa Fisher \& LaSalle (Hymenoptera: Eulophidae), causes

23 galls on Eucalyptus spp. leaf midribs, petioles and stems. Biological aspects need to be studied

24 to assist in developing management strategies and to maintain this insect in the laboratory to rear

25 the parasitoid Selitrichodes neseri Kelly \& La Salle (Hymenoptera: Eulophidae) that depends on

26 having a supply of Eucalyptus seedlings infested by L. invasa. We evaluated the longevity and

27 survival of L. invasa individual non reproductive females fed with six different diets (pure

28 honey, 50\% honey solution, pure honey plus eucalyptus leaves, eucalyptus leaves, distilled

29 water, or no food) and seven different temperatures $\left(10,14,18,22,26,30\right.$ and $\left.34^{\circ} \mathrm{C}\right)$. Leptocybe

30 invasa fed with $50 \%$ honey solution and reared at 14 or $18^{\circ} \mathrm{C}$ showed the greatest longevity and

31 survival.

32

33

34

35

36

37

38

39

40

41

42

43 
44

45

46

47

48

49

50

51

52

53

54

55

56

57

\section{Introduction}

The blue gum chalcid, Leptocybe invasa Fisher \& La Salle (Hymenoptera: Eulophidae) is a native Australian wasp and an important Eucalyptus spp. pest worldwide (Mendel et al., 2004). This insect was first reported in Mediterranean and Middle Eastern regions in 2000 (Mendel et al., 2004) and later in 39 countries (Nugnes et al., 2015). In Brazil, L. invasa was found for the first time on Eucalyptus grandis $\mathrm{x}$ Eucalyptus camaldulensis hybrid clones in northeastern Bahia in 2007 (Costa et al., 2008; Wilcken et al., 2015). This invasive wasp inserts its eggs in the epidermis of young plant parts, such as leaf midribs, petiole and stems (Zhu et al., 2013; Wilcken et al., 2015), causing galls. These galls deform leaves and terminal shoots, resulting in defoliation and drying of shoots, thereby reducing seedling and tree growth (Wilcken et al., 2015).

Highly efficient control strategies to prevent damage and manage L. invasa are unknown (Zheng et al., 2014; Wilcken et al., 2015). Chemical control showed varying success (Nyeko et al., 2007; Basavana Goud et al., 2010; Kulkarni, 2010; Jhala et al., 2010; Javaregowda et al., 2010). High costs of chemical products and likely negative effect on beneficial insects, makes this method an unfeasible option at a large plantation scale. Biological control using parasitoids constitute one L. invasa management strategy (Kim et al., 2008; Gupta \& Poorani 2009; DittrichSchröder et al., 2012). The parasitoid Selitrichodes neseri Kelly and La Salle (Hymenoptera: Eulophidae) has potential for the biological control of this pest (Kelly et al., 2012) due to its relatively short developmental time, long adult life span when supplemented with carbohydrates, ability to utilize a range of gall ages and its high host specificity (Dittrich-Schröder et al., 2014). Successful release and establishment of the parasitoid S. neseri in a Eucalyptus plantation in Brazil was demonstrated (Masson et al., 2017). Selitrichodes neseri can obtain parasitism rates 
67 over $70 \%$ in L. invasa populations in laboratory (Dittrich-Schröder et al., 2014). However, the $S$.

68 neseri mass rearing depends on having a supply of Eucalyptus seedlings infested by L. invasa.

69 Many insects, such as the parasitoids Lysibia nana Gravenhorst and Gelis agilis Fabricius

70 (Hymenoptera: Ichneumonidae) and Cleruchoides noackae Lin and Huber (Hymenoptera:

71 Mymaridae), depend on supplementary nutritional sources, such as sugar and carbohydrates, to

72 maintain their metabolism and increase their survival (Harvey et al., 2012; Souza et al., 2016).

73 Food supplements (Schamale et al., 2001; Hossain \& Haque 2015), including pollen, nectar and

74 honeydew can increase the longevity (Lee et al., 2004), fecundity and flight capacity (Winkler et

75 al., 2009), besides increasing hymenopteran survival (Luo et al., 2010).

76 Temperature can also affect insect survival (Burgi \& Mills 2013; Colinet et al., 2015; Zhu

77 et al., 2015), embryonic development, behavior and reproduction (Liu et al., 2015). Extreme

78 temperatures can reduce organism fitness (Singh et al., 2015) and holometabolic insects such as

79 L. invasa can suffer stress at different life cycle stages. Thermal stress, such as high temperatures

80 (Lieshout et al., 2013; Zizzari and Ellers 2011), can affect longevity, fecundity and fertility

81 (Hance et al., 2007; Nguyen et al., 2013), and low temperatures can reduce survival, fecundity,

82 reproduction (Lacoume et al., 2007; Singh et al., 2015) and mobility (Ayvaz et al., 2008) of 83 insects.

84 The L. invasa life-cycle varies according to the eucalypt species and climatic conditions.

85 Mean survival period for wasps fed with honey and water was 6.5 days and for three days 86 without food at $25^{\circ} \mathrm{C}$ and developmental time from oviposition to emergence was 132.6 days 87 (Mendel et al., 2004). Honey solution could prolong the longevity of L. invasa females 88 (Sangtongpraow et al., 2011). Biological characteristics, such as reproduction, fecundity, 89 oviposition behavior (Sangtongpraow et al., 2011), host range (Mendel et al., 2004) survival and 
90 longevity of L. invasa fed on different diets and exposed to different temperatures, need to be

91 studied to understand the relationship between population expansion and the environment factors

92 aimed at optimizing the rearing of this pest in the laboratory. The dispersion, methods of field

93 survey and adult biology of L. invasa have been studied (Tang et al. 2008; Wu et al. 2009; Zhu

94 et al. 2011, 2012), but temperature thresholds and diets that may affect survival and longevity of

95 this insect require further research. This information is essential to maintaining colonies of this

96 insect in the laboratory that are essential to the rearing of the parasitoid S. neseri. Therefore, the

97 aim of this study was to evaluate the effects of different diets and temperatures on longevity and

98 survival of L. invasa individual non reproductive females.

\section{Materials and Methods}

Leptocybe invasa females were obtained from a colony reared on E. grandis $\mathrm{x} E$. camaldulensis seedlings at the Laboratory of Biological Control of Forest Pests (LCBPF) of the

102 School of Agricultural Sciences, in Botucatu, São Paulo State, Brazil (2250'48,14"S; $\left.10348^{\circ} 25^{\prime} 53,52^{\prime \prime} \mathrm{W} ; 786 \mathrm{~m}\right)$. The insets are reared in cages with pure honey under in a climate room 104 at $25 \pm 2{ }^{\circ} \mathrm{C}, 70 \pm 10 \% \mathrm{RH}$ with photoperiod of $12: 12 \mathrm{~h} \mathrm{~L}: \mathrm{D}$ in Eucalyptus seedlings.

\subsection{Diet bioassays}

106

Newly-emerged L. invasa females (virgins) were placed individually in glass vials $(2.5$

$107 \mathrm{~cm}$ diameter $\times 8.5 \mathrm{~cm}$ height) capped with plastic film and fed with different diets: pure honey 108 (100\%) (T1), 50\% honey solution (T2), pure honey plus eucalyptus leaves (T3), eucalyptus

109 leaves (T4), distilled water (T5), or no food (T6). Honey was chosen as food source by ease of

110 use in laboratory rearing and eucalyptus leaves provide excellent food sources for L. invasa,

111 helping to build up abundant populations in field (Jacob and Ramesh 2009). Food was replaced 
112 every two days. Wasps were held in a climate chamber at $25 \pm 2{ }^{\circ} \mathrm{C}, 70 \pm 10 \% \mathrm{RH}$ with

113 photoperiod of 12:12 h L:D. Leptocybe invasa survival was evaluated daily.

1142.2 Temperatures bioassays

115 Newly-emerged L. invasa females (virgins) were placed individually in glass vials (2.5

$116 \mathrm{~cm}$ diameter $\times 8.5 \mathrm{~cm}$ height) capped with plastic film and maintained at temperatures of 10,14 ,

$11718,22,26,30$ and $34^{\circ} \mathrm{C}$ in a climate chamber at $70 \pm 10 \% \mathrm{RH}$ with photoperiod of 12:12 h L:D.

118 The temperature of $26^{\circ} \mathrm{C}$ was used because it is standard in rearing laboratories for many insects

119 and other temperatures $\left(14,18,22\right.$ and $\left.30^{\circ} \mathrm{C}\right)$ are representative of field conditions in Brazil.

120 The temperatures of 10 and $34^{\circ} \mathrm{C}$ were chosen as extreme conditions. These wasps were fed

121 with a 50\% honey solution, with food replaced every two days.

122 The experimental design was completely randomly with 25 replications. Therefore, 150

123 individuals were used for the diet experiment and 175 individuals for the temperature

124 experiment. Leptocybe invasa survival was evaluated daily.

$125 \quad 2.3$ Statistical analysis

126 Survival curves for L. invasa females were analyzed using Kaplan-Meier product-limit 127 estimator (Lee 1992) using SAS - Free Statistical Statistical Software, SAS University Edition.

128 These were compared using the Log-Rank test adjusted by Sidak $(P<0.05)$ (Westfall et al., 129 1999), according to two bioassays: the first experiment considered six diets and the second seven 130 temperatures.

131 2. Results

132 Diet affected L. invasa female longevity. Longevity of adult wasps was greatest when

133 fed with 50\% honey solution, 100\% honey and 100\% honey plus eucalyptus leaves, respectively.

134 Although, there is no statistical difference for longevity of wasps fed on these three diets, there 
135 seems to be some biological difference. Wasps fed a 50\% honey solution lived longer. Adding

136 foliage to the honey treatment did not change longevity compared to the wasps fed on honey

137 alone. Wasps fed only eucalyptus leaves showed similar longevity with those that were fed only

138 with water or had no food provided (Table 1). Similarly, among the three groups of females that

139 did not receive honey, there were no significant differences in survival. Females which received

140 eucalyptus leaves as food survived much longer than those receiving water or no food (Figure 1).

141 With regard to the influence of temperature on survival and longevity, longevity of $L$.

142 invasa females was highest at $14^{\circ} \mathrm{C}(33.28 \pm 3.18$ days $)$ and $18^{\circ} \mathrm{C}(29.36 \pm 3.82$ days $)$ and lower

143 at temperatures of $10^{\circ} \mathrm{C}$ and above $22^{\circ} \mathrm{C}$ (Table 2). Wasp survival was highest at $14^{\circ} \mathrm{C}$ and $18^{\circ} \mathrm{C}$.

144 Females exposed to temperatures of $10^{\circ} \mathrm{C}$ and above $22^{\circ} \mathrm{C}$ showed lower survival (Figure 2).

\section{Discussion}

Diet and temperatures affected L. invasa female longevity and survival. Wasp fed on the

$14750 \%$ honey solution, $100 \%$ honey and $100 \%$ honey plus eucalyptus leaves and reared in $14{ }^{\circ} \mathrm{C}$ 148 and $18^{\circ} \mathrm{C}$ fed on the $50 \%$ honey solution presented greater survival and longevity.

149 The observation of increased L. invasa female longevity for wasps provided with honey 150 solution is similar to that found for other Hymenoptera under laboratory conditions (Harvey et 151 al., 2012; Hossain and Haque 2015; Souza et al., 2016). For example, Cleruchoides noackae Lin 152 and Huber (Hymenoptera: Mymaridae) survived 1.2 days without food, and 3.4, 3.3 and 3.7 days 153 when provided with honey solution at 100\%, 50\%, and 10\%, respectively (Souza et al., 2016).

154 Microplitis croceipes Cresson (Hymenoptera: Braconidae) females longevity was found to be

155 four times greater when provided with honey compared to those receiving water only (Nafziger

156 Jr. and Fadamiro 2011), while Dinarmus basalis (Rondani) (Hymenoptera: Pteromalidae)

157 females survived 27.9 and 25.3 days when provided with honey and sugar solution at $10 \%$, 
158 respectively, but only 19.7 days with distilled water only (Hossain and Haque 2015). A supply of

159 honey was also found to extend the longevity of Ophelimus eucalypti (Hymenoptera:

160 Eulophidae) (Withers et al., 2000). In the present study, L. invasa longevity when not provided

161 with honey was similar to that found for Trichogramma maxacalli Voegelé and Pointel

162 (Hymenoptera: Trichogrammatidae), where adults were found to survive longer on diets

163 containing sugars than without food (Oliveira et al., 2003). These observations can be explained

164 by the honey constitution, with this food providing at least 181 nutrients such as amino acids,

165 enzymes, minerals, proteins, sugars and vitamins (Alvarez-Suarez et al., 2009).

166 Leptocybe invasa longevity and survival were affected by temperature, but in the field

167 this insect thrives under a wide temperature range (Mendel et al. 2004). Invasive species can

168 adapt to environmental factors, developing stronger tolerance and wider niche breadth. Tolerance

169 to temperature and other factors co-determined invasive species distribution and opportunity for

170 future regional dispersion (Agrawal 2001; Bale et al., 2002; Bale and Hayward 2010).

171 Differences in L. invasa longevity in relation to temperature agree with reports for other

172 hymenopterans such as Meteorus ictericus (Nees) (Hymenoptera: Braconidae) (Burgi and Mills

173 2013) and C. noackae (Souza et al., 2016). Leptocybe invasa longevity recorded at low

174 temperatures in this study was similar to that of Trichospilus diatraeae Cherian and

175 Margabandhu (Hymenoptera: Eulophidae) (Rodrigues et al., 2013).

176 Low L. invasa adult survival at higher temperatures was similar to that observed for

177 Microplitis manilae (Hymenoptera: Braconidae) (Qiu et al., 2012). Increased survival at low

178 temperatures can be associated with reduced activity and metabolism (Bleicher and Parra 1990)

179 and low females survival at higher temperatures may be due to metabolic increases or enzyme

180 destruction at higher temperatures (Mohan et al., 1992). On the other hand, these results are 
181 inconsistent with the distribution of this pest in tropical and subtropical regions, which may be

182 explained by microclimatic effects with a lower impact due to variable temperatures in the field

183 compared to the constant temperatures to which wasps were exposed to in the laboratory (Zhu et

184 al., 2015). The wasp behavior to avoiding high temperatures, such as seeking shade or cooling

185 with wing fluttering and the population and/or strain origin can also aid in adapting to different

186 conditions.

187

\section{Conclusion}

Provision of honey as a food and temperatures of 14 and $18^{\circ} \mathrm{C}$ increase L. invasa

longevity and survival. These results are important to understanding this pest biology, which is

essential to enhance methods of mass-rearing L. invasa and make feasible rearing of parasitoids

191 in laboratory. Studies should aim to explore resource utilization efficiencies in adult parasitoids

192 reared on different diets and temperatures focusing on their reproductive strategies.

193

194

195

196

197

198

200

201

202

\section{Acknowledgments}

Dr. Phillip Villani revised and corrected the English language used in this manuscript.

\section{References}

Agrawal AA. 2001. Phenotypic plasticity in the interactions and evolution of species. Science 294: $331-426$.

Alvarez-Suarez JM, Tulipani S, Romandini S, Vidal AY, Battino M. 2009. Methodological aspects about determination of phenolic compounds and in vitro evaluation of antioxidant capacity in the honey: a review. Current Analytical Chemistry 5: 293-302.

Ayvaz A, Karasu E, Karaborklu S, Tuncbilek A. 2008. Effects of cold storage, rearing temperature, parasitoid age and irradiation on the performance of Trichogramma evanescens 
Westwood (Hymenoptera: Trichogrammatidae). Journal of Stored Products Research 44: 232-240.

Bale JS, Hayward SAL. 2010. Insect overwintering in a changing climate. Journal of Experimental Biology 213: 980-94.

Bale JS, Masters GJ, Hodkinson ID. 2002. Herbivory in global climate change research: direct effects of rising temperature on insect herbivores. Global Change Biology 8: 1-16.

Basavana Goud K, Kavitha Kumar N, Vastrad AS, Bhadragoudar M, Kulkarni HD. 2010. Screening eucalyptus clones against Leptocybe invasa Fisher and La Salle (Hymenoptera: Eulophidae). Karnataka Journal of Agricultural Sciences 23: 213-214.

212 Bleicher E, Parra JRP. 1990. Espécies de Trichogramma parasitoides de Alabama argillacea. 213 Determinação das exigências térmicas de três populações. Pesquisa Agropecuária Brasileira 214 25: 215-219.

215 Burgi LP, Mills NJ. 2013. Developmental strategy and life history traits of Meteorus ictericus, a 216 successful resident parasitoid of the exotic light brown apple moth in California. Biological 217 Control 66: 173-182.

218 Colinet H, Sinclair BJ, Vernon P, Renault D. 2015. Insects in fluctuating thermal environments. 219 Annual Review of Entomology 60: 123-140.

220 Costa VA, Berti Filho E, Wilcken CF, Stape JL, La Salle J, Teixeira LD. 2008. Eucalyptus gall 221 wasp, Leptocybe invasa Fisher \& La Salle (Hymenoptera: Eulophidae) in Brazil. New forest pest reaches the new world. Revista de Agricultura 83: 136-139.

223 Dittrich-Schröder G, Harney M, Neser S, Joffe T, Bush S, Hurley BP, Wingfield MJ, Slippers B. 224 2014. Biology and host preference of Selitrichodes neseri: a potential biological control 225 agent of the eucalyptus gall wasp, Leptocybe invasa. Biological Control 78: 33-41. 
226 Dittrich-Schröder G, Harney M, Neser S, Joffe T, Bush S, Hurley BP, Wingfield MJ, Slippers B.

227 2012. Diversity in Eucalyptus susceptibility to the gall-forming wasp Leptocybe invasa.

228 Agricultural and Forest Entomology 14: 419-427.

229 Gupta A, Poorani J. 2009. Taxonomic studies on a collection of Chalcidoidea (Hymenoptera)

230 from India with new distribution records. Journal of Threatened Taxa 1: 300-304.

231 Hance T, Van Baaren J, Vernon P, Boivin G. 2007. Impact of extreme temperatures on 232 parasitoids in a climate change perspective. Annual Review of Entomology 52: 107-126.

233 Harvey JA, Cloutier J, Visser B, Ellers J, Wackers FL, Gols R. 2012. The effect of different 234 dietary sugars and honey on longevity and fecundity in two hyperparasitoid wasps. Journal 235 of Insect Physiology 58: 816-823.

236 Hossain MA, Haque MA. 2015. Influence of food supplements on the reproductive potential of 237 the parasitoid, Dinarmus basalis (Rondani) (Hymenoptera: Pteromalidae) on 238 Callosobruchus chinensis (L.) (Coleoptera: Bruchidae). African Entomology 23: 88-93.

239 Jacob JP, Ramesh AR. 2009. Incidence of galls induced by Leptocybe invasa on seedlings of 240 Eucalyptus camaldulensis and E. tereticornis from different seed sources in southern India. 241 International Journal of Ecology and Environmental Sciences 35:187-198.

242 Javaregowda J, Prabhu ST, Patil RS. 2010. Evaluation of botanicals and synthetic insecticides 243 against eucalyptus gall wasp, Leptocybe invasa (Eulophidae: Hymenoptera). Karnataka 244 Journal of Agricultural Sciences 23: 200-202.

245 Jhala RC, Patel MG, Vaghela NM. 2010. Effectiveness of insecticides against blue gum chalcid, 246 Leptocybe invasa Fisher \& La Salle (Hymenoptera: Eulophidae), infesting eucalyptus 247 seedlings in middle Gujarat, India. Karnataka Journal of Agricultural Sciences 23: 84-86. 
248 Kelly J, La Salle J, Harney M, Dittrich-Schröder G, Hurley B. 2012. Selitrichodes neseri, a new 249 parasitoid of the eucalyptus gall wasp Leptocybe invasa Fischer \& La Salle (Hymenoptera: $250 \quad$ Eulophidae: Tetrastichinae). Zootaxa 3333: 50-57.

251 Kulkarni HD. 2010. Screening eucalyptus clones against Leptocybe invasa Fisher and La Salle 252 (Hymenoptera: Eulophidae). Karnataka Journal of Agricultural Sciences 23: 87-90.

253 Kim IK, Mendel Z, Protasov A, Blumberg D, La Salle J. 2008. Taxonomy, biology and efficacy 254 of two Australian parasitoids of the eucalyptus gall wasp, Leptocybe invasa Fisher \& La 255 256 Salle (Hymenoptera: Eulophidae: Tetrastichinae). Zootaxa 1910: 1-20.

Lacoume S, Bressac C, Chevrier C. 2007. Sperm production and mating potential of males after a cold shock on pupae of the parasitoid wasp Dinarmus basalis (Hymenoptera: Pteromalidae). Journal of Insect Physiology 53: 1008-1015.

Lee ET [ed]. 1992. Statistical Methods for Survival Data Analysis. John Wiley \& Sons, New York, The United States.

261

Lee JC, Heimpel GE, Leibee GL. 2004. Comparing floral nectar and aphid honeydew diets on the longevity and nutrient levels of a parasitoid wasp. Entomologia Experimentalis et Applicata 111: 189-199.

Lieshout E, Tomkins JL, Simmons LW. 2013. Heat stress but not inbreeding affects offensive sperm competitiveness in Callosobruchus maculatus. Ecology Evolution 3: 2859-2866. on immature development of Lygus pratensis (L.) (Hemiptera: Miridae). Journal of AsiaPacific Entomology 18: 139-143. 
269 Lu T, Zhang Y, Huang Z, Huang J. 2014. The effect on the longevity of Leptocybe invasa Fisher 270 \& La Salle (Hymenoptera: Eulophidae) studied by microcalorimetry and traditional 271 methods. Journal of Thermal Analysis and Calorimetry 116: 461-467.

272 Luo SP, Li JC, Liu XX, Lu ZY, Pan WL, Zhang QW, Zhao ZW. 2010. Effects of six sugars on 273 the longevity, fecundity and nutrient reserves of Microplitis mediator. Biological Control $274 \quad 52: 51-57$.

275 Masson MV, Tavares WS, Lopes FA, Souza AR, Ferreira-Filho PJ, Barbosa LR, Wilcken CF, 276 Zanuncio JC. 2017. Selitrichodes neseri (Hymenoptera: Eulophidae) recovered from 277 Leptocybe invasa (Hymenoptera: Eulophidae) galls after initial release on Eucalyptus 278 (Myrtaceae) in Brazil, and data on its biology. Florida Entomologist 100: 589-593.

279 Mendel Z, Protasov A, Fisher N, La Salle J. 2004. Taxonomy and biology of Leptocybe invasa 280 gen. \& sp. n. (Hymenoptera: Eulophidae), an invasive gall inducer on Eucalyptus. 281 Australian Journal of Entomology 43: 101-113.

282 Mohan BR, Verma AN, Singh SP. 1992. Biology of Apanteles flavipes (Cameron) - a potential 283 parasitoid of Chilo partellus (Swin.) infesting forage sorghum. Journal of Insect Science 5: $284 \quad 144-146$.

285 Nafziger Jr TD, Fadamiro HY. 2011. Suitability of some farmscaping plants as nectar sources for 286 the parasitoid wasp, Microplitis croceipes (Hymenoptera: Braconidae): Effects on longevity 287 and body nutrients. Biological Control 56: 225-229.

288 Nguyen TM, Bressac C, Chevrier C. 2013. Heat stress affects male reproduction in a parasitoid 289 wasp. Journal of Insect Physiology 59: 248-254. 
290 Nyeko P, Mutitu EK, Day RK. 2007. Farmers' knowledge, perceptions and management of the 291 gall-forming wasp, Leptocybe invasa (Hymenoptera: Eulophidae), on Eucalyptus species in 292 Uganda. International Journal of Pest Management. 53: 111-119.

293 Nugnes F, Gebiola M, Monti MM, Gualtieri L, Giorgini M.; Wang J, Bernardo H. 2015. Genetic 294 diversity of the invasive gall wasp Leptocybe invasa (Hymenoptera: Eulophidae) and of its 295 Rickettsia endosymbiont, and associated sex-ratio differences. PLoS ONE 10: e0124660.

296 Oliveira HN, Zanuncio JC, Pratissoli D, Picanço MC. 2003. Biological characteristics of 297 298 Trichogramma maxacalii (Hymenoptera: Trichogrammatidae) on eggs of Anagasta kuehniella (Lepidoptera: Pyralidae). Brazilian Journal of Biology 63: 647-653.

Qiu BO, Zhou ZS, Luo SP, Xu ZF. 2012. Effect of temperature on development, survival, and fecundity of Microplitis manilae (Hymenoptera: Braconidae). Environmental Entomology 41: 657-644.

Rodrigues MAT, Pereira FF, Kassab SO, Pastori PL, Glaeser DF, Oliveira HN, Zanuncio JC. 2013. Thermal requirements and generation estimates of Trichospilus diatraeae

Sangtongpraow B, Charernson K, Siripatanadilok S. 2011. Longevity, fecundity and development time of Eucalyptus gall wasp, Leptocybe invasa Fisher \& La Salle (Hymenoptera: Eulophidae) in Kanchanaburi Province, Thailand. Thai Journal of Agricultural Science 44: 155-163.

310 Schmale I, Wäckers FL, Cardona C, Dorn S. 2001. Control potential of three hymenopteran 311 parasitoid species against the bean weevil in stored beans: the effect of adult parasitoid nutrition on longevity and progeny production. Biological Control 21: 134-139. 
313 Singh K, Kochar E, Prasad NG. 2015. Egg viability, mating frequency and male mating ability

314 evolve in populations of Drosophila melanogaster selected for resistance to cold shock.

315 PLoS ONE 10: 1-20.

316 Souza AR, Candelaria MC, Barbosa LR, Wilcken CF, Campos JM, Serrão JE, Zanuncio JC.

317 2016. Longevity of Cleruchoides noackae (Hymenoptera: Mymaridae), an egg parasitoid of

318 Thaumastocoris peregrinus (Hemiptera: Thaumastocoridae), with various honey

319 concentrations and at several temperatures. Florida Entomologist 99: 33-37.

320 Tang C, Wang XJ, Wan FH, Ren SX, Peng ZQ. 2008. The blue gum chalcid, Leptocybe invasa,

321 invaded Hainan province. Chinese Bulletin of Entomology 45: 967-971.

322 Torres JB, Musolin, DL, Zanuncio JC. 2002. Thermal requirements and parasitism capacity of

323 Trissolcus brachymenae (Ashmead) (Hymenoptera: Scelionidae) under constant and

324 fluctuating temperatures, and assessment of development in field conditions. Biocontrol

325 Science and Technology 12: 583-593.

326 Westfall PH, Hochberg Y, Rom D, Wolfinger R, Tobias R [eds]. 1999. Multiple Comparisons

327 and Multiple Tests Using the SAS System. SAS Institute Inc. Cary, North Carolina, The

$328 \quad$ United States.

329 Wilcken CF, Zaché B, Masson MV, Pereira RA, Barbosa LR, Zanuncio JC. 2015. Vespa-da330 galha-do-eucalipto, Leptocybe invasa Fisher \& La Salle, pp. 898-908 In Vilela EF, Zucchi

331 RA [eds.], Pragas introduzidas no Brasil: insetos e ácaros. Fealq, Piracicaba, Brasil.

332 Winkler K, Wäckers FL, Kaufman LV, Larraz V, Van Lenteren J.C. 2009. Nectar exploitation

333 by herbivores and their parasitoids is a function of flower species and relative humidity.

334 Biological Control 50: 299-306. 
335 Withers TM, Raman A, Berry JA. 2000. Host range and biology of Ophelimus eucalypti (Gahan)

336 (Hym., Eulophidae), a pest of New Zealand eucalypts. New Zealand Plant Protection 53:

$337 \quad 339-344$.

338 Wu YJ, Xi FS, Luo JT, Li DW, Chang MS. 2009. Biology and control technology of Leptocybe invasa (Hymenoptera: Eulophidae). Guangxi Plant Protect 22: 5-8.

340 Zheng XL, Li J, Yang ZD, Xian ZH, Wei JG, Lei CL, Wang XP, Lu W. 2014. A review of 341 invasive biology, prevalence and management of Leptocybe invasa Fisher \& La Salle 342 (Hymenoptera: Eulophidae: Tetrastichinae). African Entomology 22: 68-79.

343 Zhu FL, Han PF, Ren SX, Peng ZQ, Wan FH. 2011. Effect of host plants on adult biology of 344 Leptocybe invasa. Chinese Journal of Applied Entomology 48: 1451-1457.

345 Zhu FL, Qiu BL, Ren SX. 2013. Oviposition of Leptocybe invasa. Chinese Journal of Applied 346 Entomology 50: 192-196.

347 Zhu FL, Ren SX, Qiu BL, Huang Z, Peng ZQ. 2012. The abundance and population dynamics of 348 Leptocybe invasa (Hymenoptera: Eulophidae) galls on Eucalyptus spp. in China. Journal 349 of Integrative Agriculture 11: 2116-2123.

350 Zhu FL, Ren SX, Qiu BL, Wu JH. 2015. Effect of temperature on life table parameters of 351 Leptocybe invasa (Hymenoptera: Eulophidae). Austral Entomology 54: 71-78.

352 Zizzari ZV, Ellers J. 2011. Effects of exposure to short-term heat stress on male reproductive 353 fitness in a soil arthropod. Journal of Insect Physiology 57: 421-426. 
Figure 1

Survival (days) of Leptocybe invasa (Hymenoptera: Eulophidae) females reared with different diets.

Survival (days) of Leptocybe invasa (Hymenoptera: Eulophidae) females reared with 100\% honey (T1), 50\% honey solution (T2), 100\% honey supplemented with eucalyptus leaves (T3), eucalyptus leaves (T4), distilled water (T5) and no food (T6) at $25 \pm 2{ }^{\circ} \mathrm{C}, 70 \pm 10 \% \mathrm{RH}$ and photoperiod of 12:12 h L:D $(n=25)$.

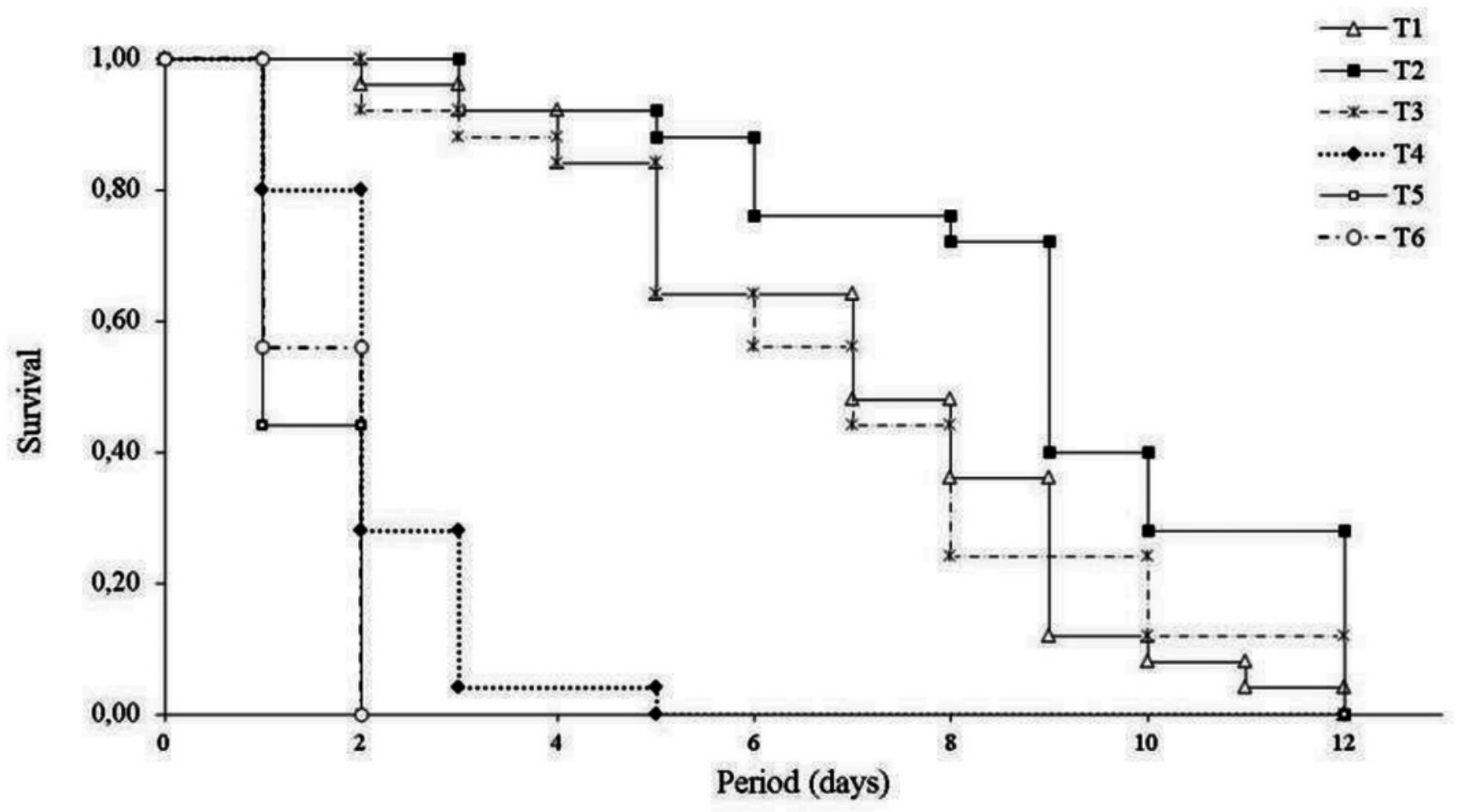


Figure 2

Survival (days) of Leptocybe invasa (Hymenoptera: Eulophidae) females at different temperatures.

Survival (days) of Leptocybe invasa (Hymenoptera: Eulophidae) females fed with a 50\% honey solution at different temperatures, $70 \pm 10 \% \mathrm{RH}$ and photoperiod of $12: 12 \mathrm{~h} \mathrm{L:D}(\mathrm{n}=$ 25).

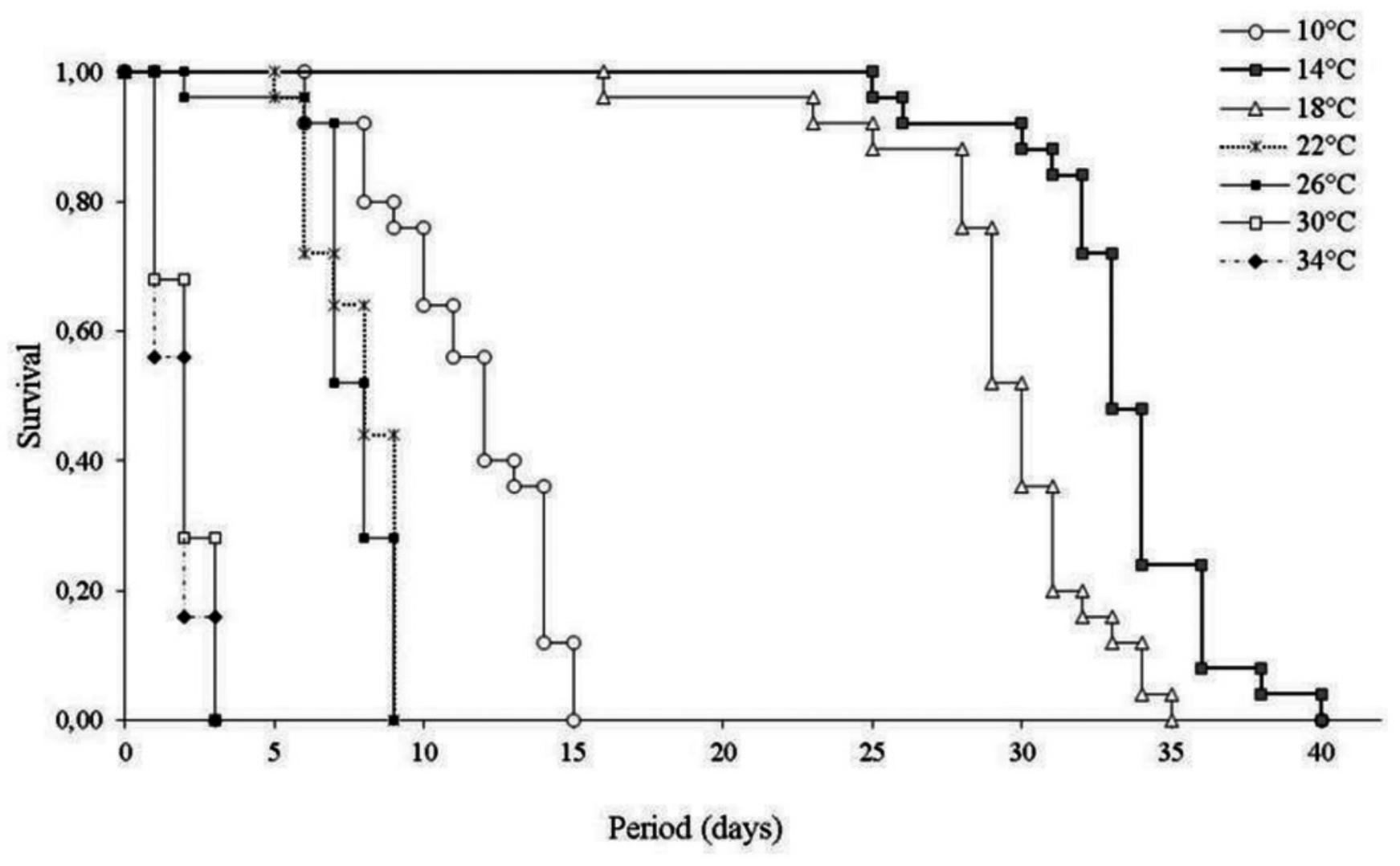




\section{Table $\mathbf{1}$ (on next page)}

Adult longevity (days) and range (days) (mean $\pm \mathrm{SE}$ ) of Leptocybe invasa

(Hymenoptera: Eulophidae) females fed with different diets at $25 \pm 2{ }^{\circ} \mathrm{C}, 70 \pm 10 \% \mathrm{RH}$ and photoperiod of $12: 12 \mathrm{~h} L: D(n=25)$.

Means followed by the same letter do not differ by the Sidak test $(P<0.05)$. 
1 Table 1. Adult longevity (days) and range (days) (mean $\pm \mathrm{SE}$ ) of Leptocybe invasa

2 (Hymenoptera: Eulophidae) females fed with different diets at $25 \pm 2{ }^{\circ} \mathrm{C}, 70 \pm 10 \% \mathrm{RH}$ and 3 photoperiod of $12: 12 \mathrm{~h} \mathrm{~L}: \mathrm{D}(\mathrm{n}=25)$

4

\begin{tabular}{lcc}
\hline Treatments & Longevity & Range \\
\hline Pure honey $(100 \%)$ & $7.08 \pm 2.54 \mathrm{a}$ & $2-12$ \\
Honey $50 \%$ & $8.92 \pm 2.75 \mathrm{a}$ & $2-12$ \\
Honey $100 \%+$ Eucal. leaves & $7.00 \pm 2.91 \mathrm{a}$ & $3-12$ \\
Eucal. leaves & $2.16 \pm 0.89 \mathrm{~b}$ & $1-5$ \\
Distilled water & $1.44 \pm 0.50 \mathrm{~b}$ & $1-2$ \\
Control (no food) & $1.56 \pm 0.50 \mathrm{~b}$ & $1-2$ \\
\hline
\end{tabular}

5 Means followed by the same letter do not differ by the Sidak test $(P<0.05)$.

6 


\section{Table 2 (on next page)}

Adult longevity (days) and range (days) (mean $\pm \mathrm{SE}$ ) of Leptocybe invasa

(Hymenoptera: Eulophidae) females exposed to different temperatures $\left({ }^{\circ} \mathrm{C}\right.$ ) at $70 \pm 10 \%$ $\mathrm{RH}$ and photoperiod of 12:12 h L:D $(n=25)$

Means followed by the same letter do not differ by the Sidak test $(P<0.05)$. 
1 Table 2. Adult longevity (days) and range (days) (mean \pm SE) of Leptocybe invasa

2 (Hymenoptera: Eulophidae) females exposed to different temperatures $\left({ }^{\circ} \mathrm{C}\right)$ at $70 \pm 10 \% \mathrm{RH}$ and

3 photoperiod of 12:12 h L:D $(n=25)$

\begin{tabular}{lll}
\hline Temperature & Longevity (days) & Range \\
\hline $10^{\circ} \mathrm{C}$ & $11.48 \pm 2.80 \mathrm{bc}$ & $6-15$ \\
$14^{\circ} \mathrm{C}$ & $33.28 \pm 3.18 \mathrm{a}$ & $25-40$ \\
$18^{\circ} \mathrm{C}$ & $29.36 \pm 3.82 \mathrm{ab}$ & $16-35$ \\
$22^{\circ} \mathrm{C}$ & $7.76 \pm 1.36 \mathrm{~cd}$ & $5-9$ \\
$26^{\circ} \mathrm{C}$ & $7.56 \pm 1.47 \mathrm{~cd}$ & $2-9$ \\
$30^{\circ} \mathrm{C}$ & $1.96 \pm 0.78 \mathrm{~d}$ & $1-3$ \\
$34^{\circ} \mathrm{C}$ & $1.72 \pm 0.73 \mathrm{~d}$ & $1-3$ \\
\hline
\end{tabular}

4 Means followed by the same letter do not differ by the Sidak test $(P<0.05)$.

5

6 